Chicago-Kent College of Law

Scholarly Commons @ IIT Chicago-Kent College of Law

All Faculty Scholarship

Faculty Scholarship

January 2011

\title{
Ethnic Cleansing as Euphemism, Metaphor, Criminology and Law
}

Todd Haugh

IIT Chicago-Kent College of Law, thaugh1@kentlaw.iit.edu

Follow this and additional works at: https://scholarship.kentlaw.iit.edu/fac_schol

Part of the Criminal Law Commons, and the Political History Commons

\section{Recommended Citation}

Todd Haugh, Ethnic Cleansing as Euphemism, Metaphor, Criminology and Law, (2011).

Available at: https://scholarship.kentlaw.iit.edu/fac_schol/297

This Contribution to Book is brought to you for free and open access by the Faculty Scholarship at Scholarly Commons @ IIT Chicago-Kent College of Law. It has been accepted for inclusion in All Faculty Scholarship by an authorized administrator of Scholarly Commons @ IIT Chicago-Kent College of Law. For more information, please contact jwenger@kentlaw.iit.edu, ebarney@kentlaw.iit.edu. 


\title{
Ethnic Cleansing as Euphemism, Metaphor, Criminology, and Law
}

\author{
John Hagan and Todd J. Haugh
}

\section{INTRODUCTION}

Euphemistic uses of the concept of ethnic cleansing are often traced to "the burning tradition" in the Balkans and the "final solution" in Nazi Germany. In this chapter, we review the origins of these euphemisms and consider how they form a backdrop for understanding the further metaphorical influence of the imagery of ethnic cleansing. Cherif Bassiouni and an international commission of experts revealed the incriminating influence of ethnic cleansing as an activating metaphor, and in this way turned the understanding of the term on its head. ${ }^{1}$ The result was to spur an international response to the massive and ongoing atrocities in the former Yugoslavia. We examine the further evolution of a social scientific understanding of ethnic cleansing as a topic of criminological study - a topic that is now evolving alongside the law of ethnic cleansing and genocide in the current epicenter of mass atrocity: Darfur.

This discussion requires that we enumerate the meaning and elements of ethnic cleansing. In doing so, we adopt a distinction between "atrocity crime" and "atrocity law" as advanced by David Scheffer. ${ }^{2}$ Accordingly, we distinguish the "criminology of mass atrocity" from "the law of atrocity." The criminology of mass atrocity involves the social scientific study of the precursors of ethnic cleansing, although it may also involve studying factors influencing whether and when these crimes will be legally prosecuted. Our use of Scheffer's distinction is less to advance the prosecution of ethnic cleansing than to increase the possibility for "real time" criminological documentation and analysis of acts of ethnic cleansing. These acts, which often extend to genocide, demand policy interventions.

Our point is that the social scientific methods of criminological documentation and analysis of acts of ethnic cleansing are important in identifying what Scheffer calls the "precursors of genocide." 3 We argue that such documentation and analysis

1 The Secretary-General, Final Report of the Commission of Experts Established Pursuant to Security Council Resolution 780 to Investigate Violations of International Humanitarian Law in the Former Yugoslavia (1992), ฯ 129-50, U.N. Doc. S/1994/674 (May 27, 1994) [hereinafter Final Report]. 2 David J. Scheffer, The Future of Atrocity Law, 25 Suffolk Transnat'L L. Rev. 389, 398 (2002).

3 David J. Scheffer, Genocide and Atrocity Crimes, 1 Genocide Stud. \& Prevention 229, 229 (2006). Such precursors might include, for example, the forced migration and large-scale displacement of civilians from their homes and properties. 
is a necessary first step to timely intervention. Our argument is focused as much or more on the prevention of ethnic cleansing and genocide as on its prosecution and punishment. Our conclusion is ultimately a call for a criminology of ethnic cleansing that will make the prospect of prosecuting mass atrocities less paralytic and more timely. We illustrate our argument by drawing on the events in the former Yugoslavia and Darfur.

\section{ETHNIC CLEANSING AS EUPHEMISM}

The history of mass atrocity is awash with euphemistic rationalizations. For example, authoritative accounts of the "burning tradition" in the Balkans, which include euphemistic references to ethnic cleansing, appear in the findings of an international observer mission sent by the American Carnegie Endowment to report on the Balkan Wars of 1912 and 1913.4 Further reports of "cleansing" in the Balkans date back to at least the early 1800 s.

In his history of the Serbs, Tim Judah writes that "Vuk Karadžić makes use of the word "cleansed' in describing what happened to the Turks of Belgrade ... in 1806." He also observes that:

[t] here was no question of this being an act of undesirable discrimination; it was simply accepted as normal for the time and place. How widespread was the massacre of the Muslims during the insurrection is unclear, yet there was no doubt that such a practice was deemed a laudable aim worth singing about. ${ }^{6}$

The Carnegie Endowment similarly reported that " $\mathrm{t}]$ he burning of villages and the exodus of the defeated population is a normal and traditional incident of ... all these peoples. What they have suffered themselves, they inflict in turn upon others."7 The euphemistic use of the term "cleansing" was thus joined with the idea that the atrocities involved were not only acceptable but desirable. References to the burning tradition and cleansing of the population treated acts such as killing one's neighbor and burning his village as expected means to the valued end of national liberation. These practices were rationalized again throughout the 1990s in the former Yugoslavia as necessary steps toward achieving a "Greater Serbia."

The "final solution" was a euphemism for the Holocaust in Nazi Germany. This extensive linguistic subterfuge also included references to cleansing. In the preface to Documents of the Persecution of the Dutch Jewry, 1940-1945, it was remarked that "these men spoke not of ... 'gassing' but of 'sonderbehandlung' (special treatment)."

4 Carnegie Endowment for Int'l Peace, Report of the International Commission to Inquire into the Causes and Conduct of Balkan Wars 73 (1914).

Tim Judah, The Serbs: History, Myth and the Destruction of Yugoslavia 75 (1997).

Id.

Carnegie Endowment for Int' L Peace, supra note 4, at 73.

Jacob Presser, Preface to Documents of the Persecution of the Dutch Jewry 1940-1945, at 10 (1969). 
The official German memorandum outlining the final solution indicated that "this discussion had been called for the purpose of clarifying fundamental questions." The memorandum went on to describe "the aim of all this being that of clearing the German Lebensraum of Jews in a legal manner," 10 and that "in the course of the practical execution of the final settlement of the problem, Europe will be cleaned up from the west to the east." 11

The challenge was to expose this euphemistic use of language for what it was - a label for organized acts of violent death and displacement - and turn it into a source of evidence for the elimination of violence as accepted practice.

\section{ETHNIC CLEANSING AS METAPHOR}

The metaphorical meaning of ethnic cleansing was captured by Mao Zedong's observation that insurgents among a civilian population are like fish swimming in water that must be drained to eliminate the fish. ${ }^{12}$ As recently as the Darfur conflict, one Sudanese ministerial official, Ahmad Harun, made a strikingly similar statement. ${ }^{13}$ According to the ICC Prosecutor who indicted Harun for war crimes and crimes against humanity, Harun stated that "rebels infiltrate the villages" and that the villages "are like water to fish." 14 The ICC Prosecutor noted that "[t]his proposition - that the potential rebel habitats or communities were as dangerous as the rebels - tellingly differed little from his [Harun's] statements that 'all the Fur,' or 3/4 of the population of Darfur, should be regarded as the target of the counterinsurgency campaign." 15 This exemplifies the sweeping metaphorical logic of the concept of ethnic cleansing.

Cherif Bassiouni seized the opportunity to change the term 'ethnic cleansing' from a rationalizing euphemism into an incriminating metaphor when he prepared the final report on violations of international humanitarian law in the former Yugoslavia. ${ }^{16}$ The most incriminating part of Bassiouni’s report for the International

9 Protocol of the Conference Held in Berlin on January 20, 1942, where measures were discussed for "Endlosung der Judenfrage," the Liquidation of the Jews (1942) in Documents of the Persecution of the Dutch Jewry 1940-1945, at 29 (1969).

10 Id.

11 Id. at 30.

12 Mao Zedong, On Guerrilla Warfare 92-93 (Samuel B. Griffith, II trans., Univ. of Ill. Press 2000) (1937).

13 Harun was charged with fifty-one counts of crimes against humanity and war crimes by the International Criminal Court. A warrant for his arrest was issued on April 27, 2007. See Off ICE OF the Prosecutor, International Criminal Court, The Situation in Darfur, Fact Sheet (Feb. 27, 2007); Prosecutor v. Harun, Case No. ICC-02/05-01/07, Warrant for Arrest of Ahmad Harun (Apr. 27, 2007).

14 Situation in Darfur, The Sudan, Case No. ICC-02/05-56, Prosecutor's Application Under Article 58(7), 147 (Feb. 27, 2007).

15 Id. 148.

16 Final Report, supra note 1, ฯ 129-50; The Policy of Ethnic Cleansing, Annex IV, U.N. Doc. S/1994/674/Add.2 (Dec. 28, 1994). 
Commission of Experts established by the United Nations' Security Council was based on 131 single-spaced pages of documentation and analysis regarding the events in Prijedor (the "Prijedor report"). ${ }^{17}$ The Prijedor report was prepared by Hanne Sophie Greve and Morten Bergsmo, who joined extensive background materials with nearly 400 interviews of victims and witnesses to the events in Prijedor. ${ }^{18}$ Names were often redacted from the report for purposes of confidentiality, but full statements were separately collected into four large volumes. These volumes were later transferred to the International Criminal Tribunal for the former Yugoslavia (ICTY) and used to guide investigations and prosecutions.

The Prijedor report argued that the facts on the ground met the elements of the crime of genocide. ${ }^{19}$ Since Greve and Bergsmo believed the events were genocide, and since the term 'ethnic cleansing' was only then beginning to enter public discourse, they did not use this term in the report. However, when Bassiouni prepared the final report of the Commission, he included a series of introductory paragraphs that explained how, in the context of the former Yugoslavia, the term 'ethnic cleansing' was widely understood to refer to the use of force and intimidation to render an area ethnically homogeneous by removing persons of other groups. ${ }^{20}$

Bassiouni further explained that the policy of ethnic cleansing was linked to political doctrines involving "Greater Serbia" and claims that date as far back as the 1389 battle in Kosovo. ${ }^{21}$ His explanation thus began to turn the rationalizing euphemism of ethnic cleansing, which was widely known and endorsed among Serbian military and political leaders, into an incriminating metaphor that social scientists could recognize as a collective framing device. ${ }^{22}$ In this context, ethnic cleansing was a way of framing an arc-like geography of aggression that began by linking Serbia proper with Serb-inhabited areas of Croatia and Bosnia, leading to the semicircular sweep of Kosovo, sometimes called Operation Horseshoe. ${ }^{23}$ Although the Prijedor report could not fully tell this still unfolding story, Bassiouni emphasized in the Final Report of the Commission that the pattern documented in Prijedor closely matched similar information received in other regions, including Banja-Luka, Brčko, Zvornik, and Foca. ${ }^{24}$

17 Final Report, Prijedor Report, Annex V, U.N. Soc. S/1994/672/Add.2 (Dec. 28, 1994) [hereinafter Prijedor Report].

18 Id. ฯ 1, 37-40.

19 Final Report, supra note 1, ฯ 182; Prijedor Report, supra note 17, ฯ 35.

Final Report, supra note 1, ฯ 129-50.

21 Id. 131. Bassiouni noted that Serbian contemporary reality was particularly affected by a vivid recollection of history, even events taking place as far back as the 1300s.

22 Robert D. Bedford \& David A. Snow, Framing Process and Social Movements: An Overview and Assessment, 26 Ann. Rev. Soc. 611 (2000). A framing device is a cognitive structure, usually consisting of a word or phrase that connects events, people, and groups into a meaningful narrative that communicates an understanding of an aspect of the social world to others.

23 Michael Ignatieff, Virtual War: Kosovo and Beyond 122 (2000). Operation Horseshoe was developed in autumn 1998 and authorized by Milošević in early 1999. Part of the Serbian "master plan," it called for a sweep of Kosovo by army and paramilitary groups that drove most of the population into Albania and Macedonia by late March.

24 Final Report, supra note 1, 140. 
Neither the Prijedor Report nor the Commission Report was presented as social science evidence. Indeed, the Reports' goal was to provide a legalistic presentation of the facts. Yet crucial social facts were included, setting a social science foundation for the claim that the atrocity crime of ethnic cleansing had been committed. For example, the Prijedor report analyzed Serbian-reported census counts, establishing that between 1991 and 1993, the Muslim population in the region decreased from 49,454 to 6,124, whereas the Serbian population increased from 47,745 to $53,637.25$

When the Prijedor team completed its report detailing the ethnic cleansing of the region, its members had no doubt about its legal meaning: "It is unquestionable that the events in Opština Prijedor since 30 April 1992 qualify as crimes against humanity. Furthermore, it is likely to be confirmed in court under due process of law that these events constitute genocide." ${ }^{26}$ Yet it was the metaphorical framing of the events in Prijedor as ethnic cleansing that persuasively summarized what happened there.

The ethnic cleansing that occurred in Prijedor was not consistently denied by Serbian authorities. The concept of cleansing was a well-known part of Serbian culture, and its consequences were confirmed by the official Serbian census statistics. A chilling confirmation that the concept of ethnic cleansing had fully circulated through Serbian leadership circles was provided by the journalist John Burns, who reported an interview with a Serbian commander Borislav Herak. In the interview, Herak confirmed that "Serbian commanders called the Serbian operation ... 'ciscenje prostora,' or the cleansing of the region, and had told the Serbian fighters to leave nobody alive."27

Bassiouni succeeded in transforming the previously euphemistic use of the concept of ethnic cleansing, and its role in rationalizing death and displacement, into a powerful metaphor that locally framed genocidal crimes in Prijedor and more widely in Bosnia and Croatia.

\section{THE MEANINGS OF ETHNIC CLEANSING}

Ethnic cleansing is generally understood as the systematic removal of a group or groups from an area by killing, expulsion, and/or imprisonment. A crucial concern is that the cleansing of ethnic groups is policy-driven. As Andrew Bell-Fialkoff explains, "ethnic cleansing can be understood as the expulsion of an 'undesirable' population from a given territory due to religious or ethnic discrimination, political, strategic or ideological considerations, or a combination of these."28

Although the UN General Assembly has identified ethnic cleansing as a violation of international humanitarian law and explicitly declared that "the abhorrent

Id. 153.

Id. 182; Prijedor Report, supra note 17, 35.

27 John F. Burns, A Killer's Tale - Special Report: A Serbian Fighter's Path of Brutality, N.Y. Times, Nov. 27, 1992, at Al.

28 Andrew Bell-Fialkoff, A Brief History of Ethnic Cleansing, Foreign AfF., Summer 1993, at 110. 
policy of "ethnic cleansing' ... is a form of genocide,"29 the concept is better understood as overlapping with and extending beyond genocide. For example, in the trial of Milomir Stakić on charges of genocide in Prijedor, the ICTY Trial Chamber observed that despite obvious similarities between genocidal and ethnic cleansing policies, a "clear distinction must be drawn between physical destruction and mere dissolution of a group. The expulsion of a group or part of a group does not in itself suffice for genocide." ${ }^{30}$

To be genocide, ethnic cleansing must be intentional and fall within one of the categories of acts of group or partial group destruction explicitly prohibited by the Genocide Convention. The genocidal activity most likely to occur in situations of ethnic cleansing is the "deliberate[] inflicti[on] on the group conditions of life calculated to bring about its physical destruction in whole or in part." 31 Of course, the imprecise reference to whole or partial destruction is an issue for consideration. The precise and intended targeting of a group for ethnic cleansing may also be unclear. As a result, some ethnic cleansing more easily fits within the meaning of crimes against humanity, as a "widespread or systematic attack directed against any civilian population." 32

Dražen Petrović further categorizes types of conduct recognized as component parts of ethnic cleansing. These categories include: (1) administrative measures, such as removal from employment and elected positions, and interference with mobility and access to essential goods and services; (2) other nonviolent measures, such as threatening media attention and harassment and related forms of intimidation; (3) terrorizing measures, such as deportation, detention, discrimination, and displacement, which are usually illegal, threatening, and harmful; and (4) military measures, such as attacking and laying siege to a locality, and detaining, deporting, and executing leaders and citizens. ${ }^{33}$ However, Petrovic emphasizes that all of these measures and more can also be treated as isolated violations of human rights and humanitarian law while overlooking or underemphasizing their systematic and collective structure, which is a distinctive characteristic of ethnic cleansing. ${ }^{34}$

To capture the systematic and collective aspect of ethnic cleansing, which he regards as central, Petrović urges particular attention be paid to the goals of cleansing acts. He also draws attention to the motivating policies of the involved parties,

29 The Situation in Bosnia and Herzegovina, G.A. Res. 47/121, pmbl., U.N. Doc. A/RES/47/121 (Dec. 18, 1992).

30 Prosecutor v. Stakić, Case No. IT-97-24-T, Judgment, 519 (July 31, 2003).

31 Convention on the Prevention and Punishment of the Crime of Genocide, art. 2, Dec. 9, 1948, 102 Stat. 3045, 78 U.N.T.S. 277 [hereinafter Genocide Convention]; Rome Statute of the International Criminal Court, Conference of Plenipotentiaries on the Establishment of an International Criminal Court, art. 6, July 17, 1998, U.N. Doc. A/CONF.183/9 [hereinafter Rome Statute].

32 Rome Statute, supra note 31, art. 7.

33 Dražen Petrović, Ethnic Cleansing - An Attempt at Methodology, 5 Eur. J. InT'L L. 342, 345-48 (1994).

34 Id. at 348. 
both in the form of organized attacks and counterattacks. Petrovićs understanding is that:

[E]thnic cleansing is a well-defined policy of a particular group of persons to systematically eliminate another group from a given territory on the basis of religious, ethnic or national origin. Such a policy involves violence and is very often connected to military operations. It is to be achieved by all possible means, from discrimination to extermination, and entails violations of human rights and international humanitarian law. ${ }^{35}$

Petrovic is clearly correct that the "systematic elimination" aspect of ethnic cleansing is central to its overlap with genocide, but also involves a potential extension beyond the meaning of genocide. We argue that establishing whether "systematic elimination" is present involves using a mixture of social scientific criminological and legal evidence, with the criminological evidence often playing a leading role.

Petrović identifies several forms of evidence of systematic elimination that depend on intent. ${ }^{36}$ The degree of intent present bears on the overlapping meanings of ethnic cleansing and genocide. ${ }^{37}$ Petrovic acknowledges the rarity of finding explicit written materials and public statements of official intentions. ${ }^{38}$ This kind of material is especially difficult to uncover in "real time," since it is often hidden from public view.

In a vivid illustration of the complex problems involved in obtaining and introducing explicit evidence of specific intent, the ICTY Trial Chamber ultimately could not accept into evidence a recorded audio intercept of General Radislav Krstić issuing a command in Srebrenica to "kill them all." ${ }^{39}$ The rejection of this evidence occurred even though the intercept was repeatedly heard in court and subjected to extensive expert testimony. ${ }^{40}$ This experience highlights important issues of what will be deemed "sufficient evidence" of genocidal intent. We maintain that social science documentation and criminological analysis, in addition to legal evidence, can occupy a crucial space between what we have followed Scheffer in calling the criminology of mass atrocity, as distinct from mass atrocity law.

Petrović identifies two probative indicators of genocidal intent that he regards as constituting "sufficient evidence." The first is the participation of government authorities in atrocities or their omission to prevent or punish the perpetration

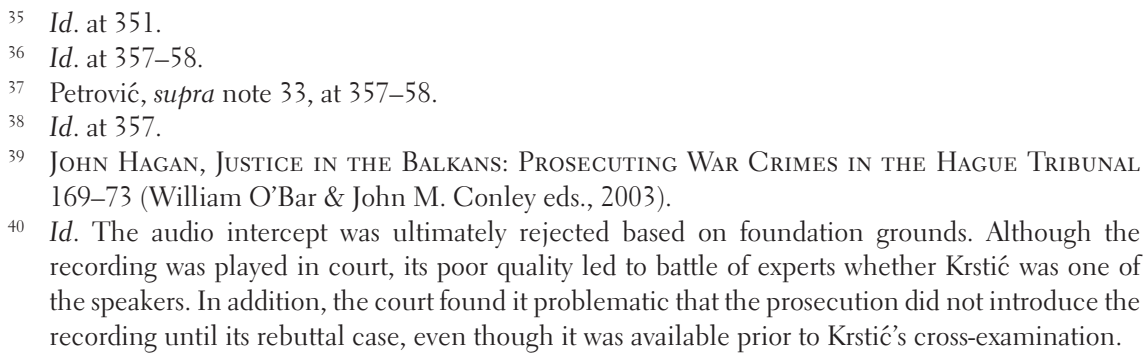

40 Id. The audio intercept was ultimately rejected based on foundation grounds. Although the recording was played in court, its poor quality led to battle of experts whether Krstić was one of the speakers. In addition, the court found it problematic that the prosecution did not introduce the recording until its rebuttal case, even though it was available prior to Krstićs cross-examination. 
of these crimes. ${ }^{41}$ The second is the identification of civilian groups rather than military forces as targets of war. ${ }^{42}$

Petrović also identifies more specific evidence of circumstances indicating ethnic cleansing and genocide:

These elements could be: a profile of the population killed (sex, age, social position, specific categories, level of education, etc.), characteristics of individual crimes committed (brutality, cruelty, humiliation, etc.), the systematic nature of certain crimes (rape, destruction of property and objects necessary for survival of population, destruction of places of worship, prevention of delivery of humanitarian aid, etc.). ${ }^{43}$

Courts will ultimately decide which kinds and combinations of the above evidence revealed in the criminology of mass atrocity are crucial to the atrocity law of genocide and ethnic cleansing.

First, however, evidence of the above elements necessary for assessing intent must be documented and analyzed. Building on Scheffer's distinction, the range of possibilities involved in this determination opens up important space and motivation for criminological documentation and analysis of atrocity crimes - that is, a criminology of mass atrocities that can form the foundation for atrocity law determinations. We elaborate and illustrate this point next by reviewing the analyses of episodes of ethnic cleansing in Kosovo and Darfur.

\section{THE KOSOVO PHASE OF THE MILOŠEVIĆ TRIAL}

The early phase of the trial of Slobodan Milošević at the ICTY provides a vivid example of how the combined use of social scientific criminological documentation and analysis and more conventional eyewitness evidence may identify the necessary intent to establish the "precursors of genocide." ${ }^{44}$ Even earlier availability of such evidence, in the manner we follow Scheffer in advocating, might arguably have more successfully forestalled the mass atrocities that took place in Kosovo.

The first phase of the Milošević trial included the testimony of Patrick Ball, a young sociologist and statistician. Ball presented results from a statistical study that, at one point, involved him retrieving data on displaced refugees through a barrage of gunfire at a Kosovo border crossing. ${ }^{45}$ His testimony was introduced to refute Milošević's defense that NATO bombings and attacks by the Kosovo Liberation Army (KLA) were actually to blame for the exodus of refugees from Kosovo.

Ball was able to identify 4,400 persons killed in Kosovo. ${ }^{46}$ He then used population sampling methods to estimate that the death toll in Kosovo was more than

41 Petrović, supra note 33, at 357.

42 Id. at 358.

43 Id.

44 Scheffer, supra note 3, at 229.

45 Prosecutor v. Milošević, Case No. IT-02-54-T, Trial Transcript, 2146 (Mar. 13, 2002).

46 Id. at 2165. 
$10,000 .{ }^{47}$ Ball presented evidence that the geographic and temporal distribution of the dead across Kosovo corresponded closely to refugee movements. He concluded that the deaths and the refugee movements were the result of a common cause. ${ }^{48}$

The Milošević defense claimed the deaths and refugee movements were the joint products of NATO bombing and KLA terrorism. Yet Ball was able to show that surges in refugee flows followed Serbian military activity; that NATO bombing and KLA activity followed, rather than preceded, Serbian military activity; and that NATO and KLA actions followed increases in refugee movements. Ball testified that "the findings of this study are consistent with the hypothesis that action by Yugoslav forces was the cause of the killings and refugee flow." ${ }^{49}$ Milošević characteristically responded during cross-examination that "statistics ... can prove anything ... and this is done to serve the purposes of the American politics aimed at enslavement." 50 He then turned, in a somewhat less ad hominem fashion, to the specifics of Ball's analysis.

Milošević questioned how Ball's analysis could transform the 4,211 dead into "the invented figure of 10,356" and then distribute them across time and place. ${ }^{51}$ When Ball identified the statistical procedures involved, Milošević responded, "[s]o you distributed the assumed dead into assumed time points by applying some kind of statistical methods. How can that be a serious way of doing it? Tell me." 52 Ball explained that he and his colleagues used accepted methods to compensate for the missing data, and included cautionary warnings wherever noteworthy doubts emerged..$^{53}$

Milošević accused Ball of simplifying war with statistics. ${ }^{54}$ Milošević asserted that if the Tribunal took seriously Ball's hypothesis that Yugoslav forces provoked the exodus from Kosovo, then there must be some still unproven official plan. ${ }^{55}$ This was a demand for very specific and explicit evidence of intent. As we note earlier, this type of evidence is seldom uncovered. The refusal of officials in Belgrade to allow access to Yugoslav military archives made such evidence of specific intent very unlikely. Milošević persisted: "So I'm asking you: if the Yugoslav authorities planned and carried out a centrally organized campaign, where is the plan? What is it called and who made it?"56

When Ball stuck to his hypothesis-driven analysis of the patterns revealed in the data on death, displacement, NATO bombing, and KLA attacks, Milošević pressed his contention that there was no credible documentary evidence of an official government plan. He followed with the observation that "you are aware of the statement

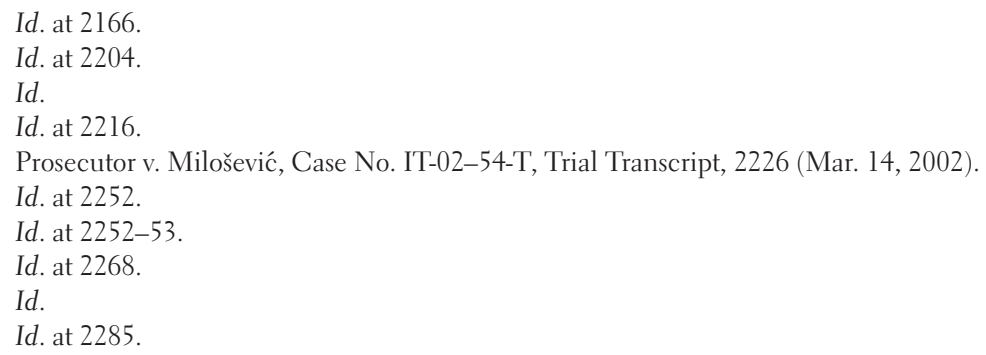


of one of the NATO Defense Ministers, the German Minister, Rudolph Scharping, who said that there was a plan, the Horseshoe Operation, and this claim was later refuted ... Are you aware of that?"57 The Presiding Judge, Richard May, said that Operation Horseshoe was neither within Ball's expertise, nor part of his testimony. ${ }^{58}$ Ball had established a prima facie case based on statistical patterns suggesting the deadly role of the Yugoslav forces, but it was also clear that Milošević had raised the issue of specific intent in a challenging way.

The Prosecution followed Ball's presentation of the statistical evidence with a form of eyewitness evidence. The evidence was introduced through the testimony of Paddy Ashdown, a former member of the British Parliament who played several diplomatic and administrative roles in the Balkan conflict. ${ }^{59}$ Ashdown's involvement exemplifies Scheffer's discussion of the "precursors of genocide."

Ashdown visited the Balkans in June 1998 in an effort to observe what was then unfolding in "real time" in Kosovo. ${ }^{60}$ Although he was denied entry to Kosovo itself, Ashdown, positioned on the Albanian side of the border, used binoculars to witness gunfire and the torching of Kosovar villages. ${ }^{61}$ This was an indication of "the burning tradition" of ethnic cleansing in the Balkans. After reporting his observations to British Prime Minister Tony Blair, Ashdown returned to western Kosovo in September 1998. ${ }^{62}$ Ashdown witnessed firsthand the burning and bombardment of whole villages - scenes that were captured on video. ${ }^{63}$

Ashdown traveled to Belgrade to meet with Milošević in person. Ashdown described during the trial what he said to the Serbian leader. He told Milošević that:

[W]hat I had witnessed could only be described as the actions of the main battle units of the Yugoslav army in an action which could only be described as indiscriminate, punitive, designed to drive innocent civilians out of their properties, could not be explained by any targeting military operation, that this was ... not only illegal under international law, damaging to the representation of the Serbs and his nation, but also deeply counter-productive. ${ }^{64}$

Ashdown further reported warning Milošević that "the international community will act if you do not stop." 65 When Milošević initiated his cross-examination of Ashdown in court, Ashdown took the opportunity to again remind Milošević of what was said.

I said to you, in specific terms, that if you went on acting in this fashion, you would make it inevitable that the international community would have to act, and in the

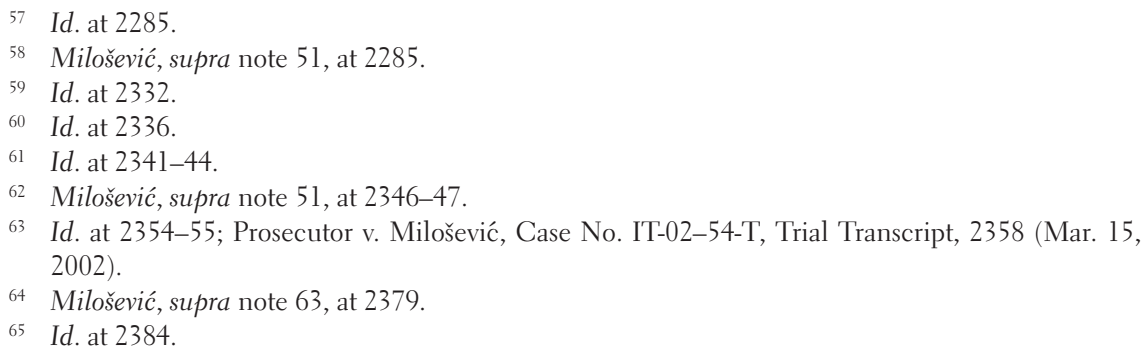


end they did have to act. And I warned you that if you took those steps and went on doing this, you would end up in this Court, and here you are. ${ }^{66}$

Ashdown was later asked a question from one of the judges about his sense of what knowledge Milošević had of the atrocities occurring in Kosovo. Ashdown stated:

I must presume that he [Milošević] knew about it, but I wanted to make explicitly clear that from the moment I had informed him and had drawn his attention to the provisions of international law, the Geneva Convention, from that moment onwards, he could not then deny knowledge of these facts if they were to continue. ${ }^{67}$

Similar testimony was offered by William Walker, the U.S. Ambassador and head of the Kosovo Verification Mission, and by Klaus Naumann, the German NATO military commander.

Patrick Ball's statistical analysis and Paddy Ashdown's eyewitness testimony constitute evidence of Scheffer's "precursors of genocide." Ball's analysis and Ashdown's testimony, as they unfolded during the trial, also illustrate what Scheffer calls atrocity law. Scheffer's further point is that by opening up a recognized and accepted space between the finding of evidence of atrocity crime and the unfolding of atrocity law, we can encourage the "real time" collection of evidence of the precursors of genocide in an even more proactive manner than this ICTY example provides. For example, if Ball's social scientific criminological analysis had been completed even earlier, in time for presentation not only to Milošević during Ashdown's Belgrade confrontation, but also at a court hearing of the evidence, it is possible that the atrocities in Kosovo might have been more effectively forestalled. This could conceivably have taken place in "real time," as the events were happening, and in advance of the retrospective unfolding of the earlier described atrocity law at the ICTY trial.

\section{PRECURSORS OF GENOCIDE AND THE ETHNIC CLEANSING OF DARFUR}

Ethnic cleansing, if not genocide, is still ongoing in Darfur. ${ }^{68}$ This presents a timely opportunity to see how a social scientific criminological approach to mass atrocity can set a persuasive foundation for intervention and legal prosecution. We present our own research on Darfur, which builds on earlier work of the U.S. State Department.

We conceive the genocide charge in Darfur to be as follows: The government of Sudan knowingly mobilized and collectivized a racially constructed division

66 Id. at 2395.

67 Id. at 2497.

68 Prosecutor v. Harun, Case No. ICC-02/05-01/07, Warrant for Arrest of Ahmad Harun (Apr. 27, 2007) (charging fifty-one counts of crimes against humanity and war crimes, including what could be characterized as the systematic murder of the civilian Fur population in Kadoom villages). 


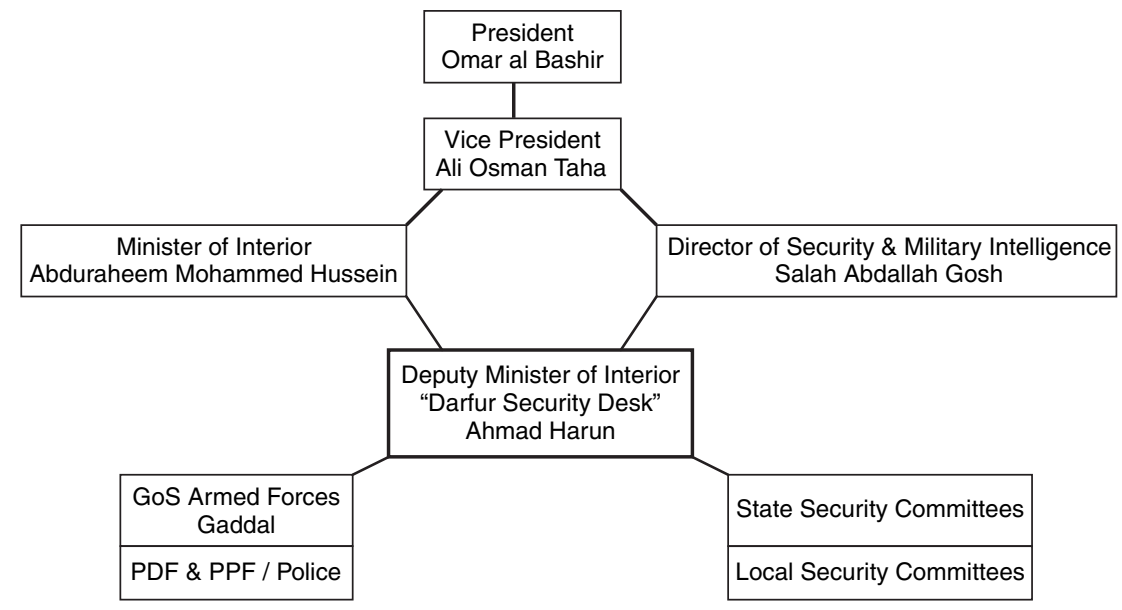

\begin{tabular}{|c|c|c|c|}
\hline \multicolumn{4}{|c|}{ Janjaweed / Militia Leaders } \\
\hline Musa Hilal & Hamid Dawai & Abdullah Mustafa Abu Shineibat & Ali Kushayb \\
\hline \multicolumn{3}{|c|}{ Settlement \& Sub-Localities } \\
\hline $\begin{array}{c}\text { Kabkabaya- } \\
\text { Kutum-Karnoi }\end{array}$ & $\begin{array}{c}\text { Terbeba-Arara- } \\
\text { Beida }\end{array}$ & Habila-Foro Burunga & $\begin{array}{c}\text { Mukjar-Bindisi- } \\
\text { Garsila-Deleig }\end{array}$ \\
\hline
\end{tabular}

Identified in ICC Prosecutor's Application

FIGURE 8.1. Sudan-Darfur chain of command, 2003-2004.

between the Arab and black African groups in Darfur to intentionally bring about the death, destruction, and displacement of those black African groups. Although documentary evidence is thus far scarce, we will infer from the statistical evidence below that there was authorization from the highest levels of the Sudanese government, as indicated in Figure 8.1, for coordinated, racially targeted attacks on African farms and villages by Government of Sudan $(\mathrm{GoS})$ military forces and Arab Janjaweed militias. As one refugee in the survey described below reported, "they come together, they fight together, and they leave together." ${ }^{69}$

The ICC Prosecutor has identified President Omar Al-Bashir, former Deputy Minister of Interior Ahmad Harun, and the militia leader Ali Kushayb as joint participants in the mass atrocities in Darfur. ${ }^{70}$ In addition to these individuals, Figure 8.1 identifies three other militia leaders who participated in mass atrocities in connection with Deputy Minister Harun. This "chain of command" comes from the

69 John Hagan \& Wenona Rymond-Richmond, Darfur and the Crime of Genocide 116 (2009) (quoting Sudan: Peace But at What Price?: Hearing Before the S. Comm. On Foreign Relations, 108th Cong. 52-62 (2004) (statement of Julie Flint, Darfur field researcher, Human Rights Watch).

70 Id. at $105,114-15$. 
documentation and analysis of a U.S. State Department survey of refugees in Chad, which we discuss below.

In June 2004, a U.S. official placed the Sudan government on notice that its coordinated attacks on villages in Darfur were being observed and recorded with satellite and aerial imagery. ${ }^{71}$ Although these attacks were at a minimum signs of ethnic cleansing, as well as "precursors of genocide," the official cautioned "that the images are not hard evidence until they are corroborated by testimony of witnesses on the ground." 72 Therefore, during the following July and August, the U.S. State Department, at the direction of Secretary of State Colin Powell, conducted the Atrocities Documentation Survey (ADS). The ADS was a survey of 1,136 refugees who witnessed and experienced attacks in Darfur, but were now living in Chad. ${ }^{73}$

An eight-page summary of the ADS survey, which included a table of descriptive statistics and maps, formed the background for Secretary of State Powell's testimony on September 9, 2004 to the U.S. Senate Foreign Relations Committee, stating that genocide was occurring in Darfur. ${ }^{74}$ This summary report, however, was only the first step in the development of a criminology of the mass atrocities that were still underway. We report next how we have used the ADS survey to document and analyze the mass atrocities of ethnic cleansing in Darfur. The point is to illustrate how a criminological analysis of these mass atrocities can set the foundation for the development of the atrocity law of Darfur in future prosecutions.

The ADS data uniquely and extensively documented victimization during the attacks on black African settlements in Darfur. We know of only one other systematic study of precamp violence in Darfur, ${ }^{75}$ and none that includes sexual violence. As part of the ADS survey, refugees were asked, since the beginning of the conflict approximately eighteen months earlier: (1) when, how, and why they had left Darfur; and (2) if, when, how, and by whom they, their family, or their fellow villagers were harmed. ${ }^{76}$

The survey mixed the closed-ended format of health and crime victimization surveys with the semistructured format of legal witness statements. ${ }^{77}$ With the State Department's geospatial technology, cartographers, translators, and interviewers' notations, we were able to locate 90 percent of the settlements from which the

71 News Release, Monica Amarelo, American Association for Advancement of Science, Using Science to Gauge Sudan's Humanitarian Nightmare, (Oct. 26, 2004), available at http://www. aaas.org/news/releases/2004/1026sudan.shtml

72 Id.

73 Id.

74 Bureau of Democracy, Human Rights, and Labor \& Bureau of Intelligence and Research, U.S. Dep't of State, Documenting Atrocities in Darfur (2004), available at http://2001-2009.state.gov/g/drl/rls/36028.htm

75 Evelyn Deportere etal., Violence and Mortality in West Darfur, Sudan (2003-2004): Epidemiological Evidence from Four Surveys, 364 LANCET 1315-20 (2004).

76 Bureau of Democracy, Human Rights, and Labor \& Bureau of Intelligence and RESEARCH, supra note 74 .

77 Cyrena Respini-Irwin, Geointelligence Informs Darfur Policy, Geointelligence, Sept./Oct. 2005, at 18, 19-22; see also HaGan \& Rymond-Richmond, supra note 69, at 170. 
refugees fled. ${ }^{78}$ In total, 932 of the 1,136 refugees were identified as coming from 22 settlements, each with 15 or more respondents. ${ }^{79}$ We cross-checked and supplemented the ADS data by rereading and recoding the extensive narratives recorded in the interviews. ${ }^{80}$

The ADS refugee sample provides a descriptive picture of the results of ethnic cleansing in Darfur. About 40 percent of the ADS respondents are male and they are on average thirty-seven years old. ${ }^{81}$ Female refugees probably outnumber males because in Darfur, males are more likely to be killed whereas females are more likely to be raped and survive, at least physically. Slightly more than half of the Africans in the sample are self-identified as Zaghawa, approximately a quarter are Masalit, and about 5 percent each are Fur and Jebal. ${ }^{82}$ The largest concentrations of the Zaghawa fled from North Darfur, whereas most of the Masalit and Fur fled from West Darfur, with the Jebal previously concentrated in one town, Seleya, in West Darfur. ${ }^{83}$ The documentation of the victimized groups is crucial to establishing the protected status of the victims of the mass atrocities.

Each attack narrative was read and coded to designate the attacking group as Janjaweed, Sudanese, or combined Sudanese and Janjaweed forces. About two thirds of the attacks were joint Sudanese and Janjaweed operations; nearly a fifth of the attacks involved Sudanese forces acting alone (usually in bombing attacks); and about one-tenth involved the Janjaweed alone. ${ }^{84}$ The remaining ten percent of cases could not be categorized but are used as a comparison group in some of our analyses. ${ }^{85}$ The documentation of when the attacks included Sudanese military forces is crucial to establishing the role of Sudanese government policy in the mass atrocities.

During the second two-week period of the ADS interviews, a question was added asking if there were rebels actually staying in the respondent's town or village. ${ }^{86}$ Less than two percent of the respondents in the sample reported a rebel presence. ${ }^{87}$ These reports were disproportionately located in several northern settlements, such as Karnoi, near Tine, and Girgira, with the reporting of rebel presence still low, but ranging from six to thirteen percent. ${ }^{88}$ The documentation of rebel involvement in the settlements that were attacked is crucial to refuting the Sudanese government's defense that it was acting in proportionate self-defense against an organized insurgency.

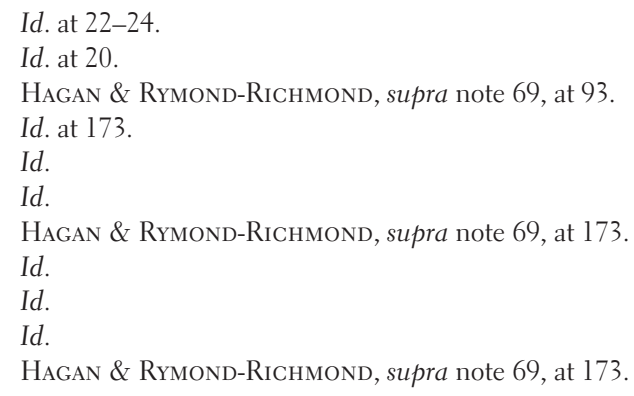




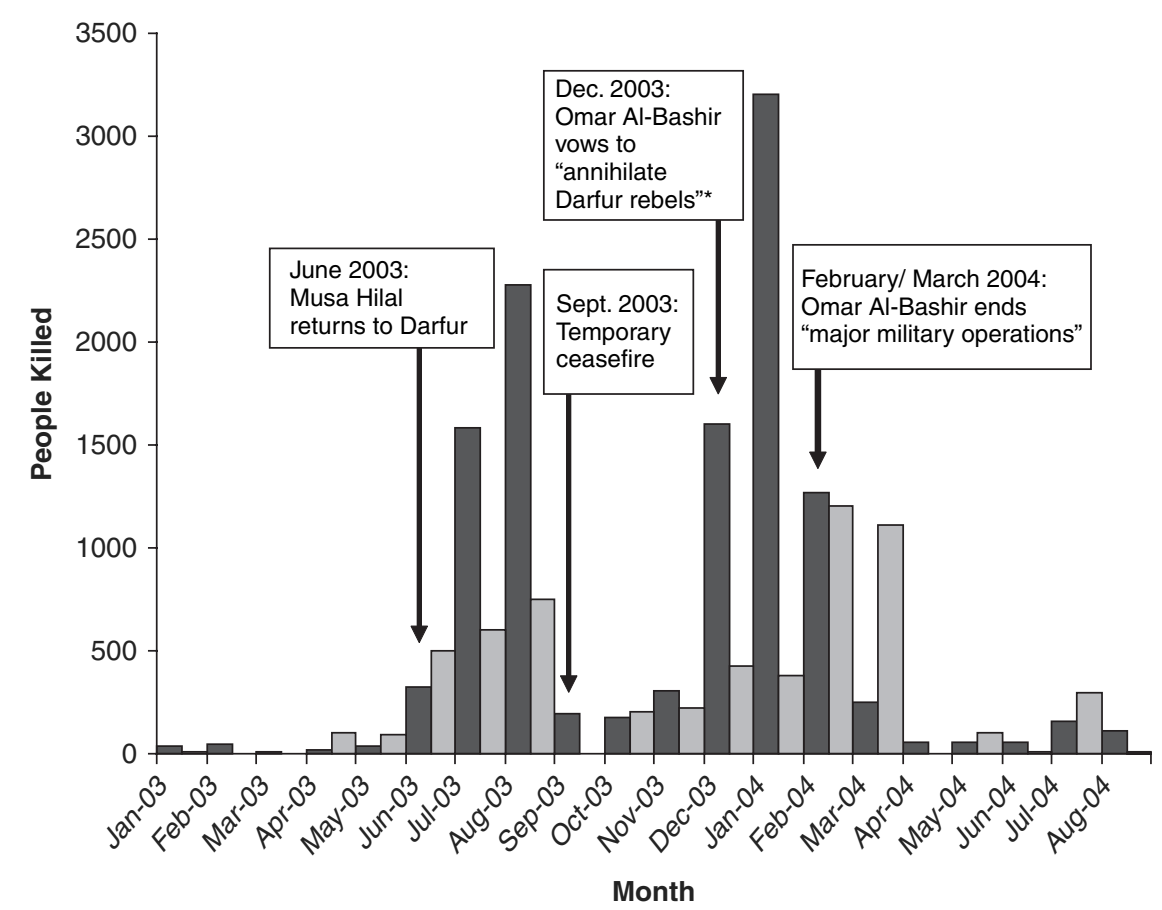

Survey count of killings

News count of killings

FIGURE 8.2. Chronology of key events and monthly death estimates from survey and news counts of killings, January 2003-September 2004.

There were two waves of attacks in Darfur, and these predictably corresponded with the peak periods of ethnic cleansing involving violent and health-related death and displacement. About a quarter of the sample fled during the first three months of first wave attacks, about half fled during the four months of the second wave of attacks, with the remaining quarter fleeing during the other thirteen months. ${ }^{89}$ The second wave of attacks was obviously the most costly in terms of the physical destruction of the group conditions of social life for Africans in Darfur. It was during the second wave of attacks, in December 2003, that Sudanese President Omar Al-Bashir vowed to "annihilate Darfur rebels." 90 Figure 8.2 shows monthly death counts from January 2003 to September 2004, encompassing the two waves of attacks as well as the months before and after. The two sources are the ADS interviews and a separate survey based on news and NGO reports of deaths in attacks on 101 villages. ${ }^{91}$

89 Id.

90 Id. at 139-40.

91 Id. at 139. 
The death toll in Darfur for this eighteen-month period is estimated at between 200,000 and 400,000. ${ }^{92}$

The ADS interviews are highly detailed in recording the shouting of racial epithets - our measure of racial intent - during the attacks. The epithets are important, in part, because they provide evidence of an explicit targeting that focused the attacks in a way that went beyond the multiple ethnic tribal identities indigenous to Darfur (i.e., the Zaghawa, Fur, and Masalit). The effect of these epithets was to identify an explicit binary racial division. As we see next, although both ethnic and racial groups are protected under the Genocide Conventions, ethnic attributions are more easily dismissed as subjectively and internally adopted by the groups themselves.

The UN International Commission of Inquiry approached this distinction involving subjective and objective identity as an important issue of atrocity law. This is an example of how Scheffer argues that the exclusively legal framing of such issues can inhibit parties from acting on their responsibility to protect victimized groups. ${ }^{93}$ The UN Commission concluded that victims of violence in Darfur were not objectively distinct from their attackers and recognizable as protected ethnic or racial groups under the Genocide Convention:

The various tribes that have been the object of attacks and killings (chiefly the Fur, Masalit and Zaghawa tribes) do not appear to make up ethnic groups distinct from the ethnic group to which persons or militias that attack them belong. They speak the same language (Arabic) and embrace the same religion (Muslim). In addition, also due to the high measure of intermarriage, they can hardly be distinguished in their outward physical appearance from the members of tribes that allegedly attacked them. ${ }^{94}$

The UN Commission failed to acknowledge that racial distinctions are often socially constructed and forcefully imposed with little regard to physical difference. Racial epithets are important for both criminological and legal analysis because they capture the motivation and intent of attackers. The frequently quoted Akayesu decision in Rwanda ${ }^{95}$ and the Jelisić decision in Bosnia ${ }^{96}$ both emphasize the importance of spoken language in genocide. Social science evidence regarding the influence of racial epithets is shown below to have an important bearing on the criminology and law of mass atrocity in Darfur.

We examined the narrative accounts of the attacks on a case-by-case basis to find reports of victims and refugees hearing racial epithets. We recorded the content of the epithets, detailing as exactly as possible the wording of the epithets, and each individual was assigned a code indicating whether or not they heard racial epithets.

92 John Hagan \& Alberto Palloni, Death in Darfur, Science, Sept. 15, 2006, at 1578-79.

93 Scheffer, supra note 3, at 248.

94 U.N. International Commission of Inquiry, Report of the International Commission on Darfur to the United Nations Secretary-General, 508, U.N. Doc. S/2005/60 (Feb. 1, 2005).

95 Prosecutor v. Akayesu, Case No. ICTR-96-4-T, Judgment, đฯ 698-734 (Sept. 2, 1998).

96 Prosecutor v. Goran Jelisić, Case No. IT-95-10-T, Judgment, ฯฯ $73-77$ (Dec. 14, 1999). 


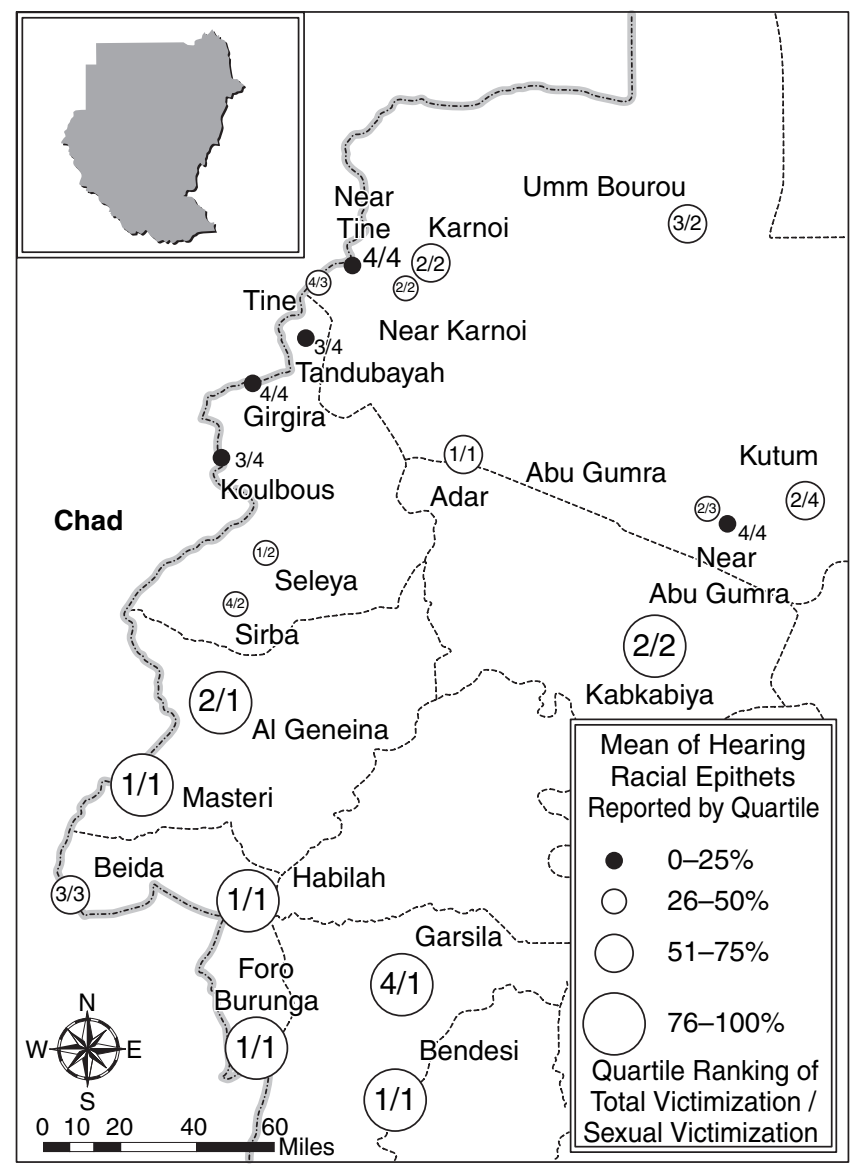

MAP 8.1. Settlement cluster map of racial epithets and total victimization and sexual victimization.

Respondents reported hearing racial epithets, as indicated on the accompanying Map 8.1, in all the settlements, with about a quarter to half of the respondents hearing them across the twenty-two settlements. ${ }^{97}$ Overall, about one-third of the respondents heard racial epithets during the attacks. ${ }^{98}$ These epithets were explicit, often invoking images of racial slavery, and they constitute concrete, first-person evidence of racial intent.

We argue that the racial epithets combine elements of motivation and intent, and that they were raised to compelling collective levels in the settings where they were most frequently heard. The racial component of the epithets is the motivational element. The intent element includes the targeted references to killing, raping, assaulting, looting, and destroying group life.

97 Hagan \& Rymond-Richmond, supra note 69, 172-73.

98 Id. 
Refugees often reported hearing the incoming forces shouting racial slurs, such as "this is the last day for blacks," "[w]e will destroy the black skinned people," "kill all the slaves," "kill all the blacks," "you are black, you deserve to be tortured like this," and "we will kill any slaves we find and cut off their heads." These words and phrases shouted by the perpetrators provide insight into and evidence of the attackers' motivation and intentions during the raids on Darfurian villagers. We shorten the reference to "collective racial intent" below, but it is noteworthy that both motivation and intent are involved in the reported racial epithets.

In addition to situating the refugees in terms of prior rebel activity in their settlements and the hearing of racial epithets during the attacks, it is also important to consider the density of the population settlements in which they lived. The more densely settled areas of Darfur are also the most fertile in providing the necessary conditions for group life that are importantly highlighted in the Genocide Convention. ${ }^{100}$ We developed a measure for density consisting of the number of settlements in an area recorded in the UN Humanitarian Information Profiles (the numerator), and the square kilometers in the area (the denominator).

Settlement density is more than a measure of the population at risk of victimization. It is also a measure of criminal opportunities and incentives, including desirable property consisting of possessions, livestock, and the settled land itself. The settlements that score highest on this settlement density measure are in the southwestern area of West Darfur, including Bendesi, Foro Burunga, Habiliah, and Masteri. Settlement of a land area effectively constitutes ownership in Darfur, and in a time of desertification and recurrent famine, access to settled land is often a crucial resource for sustaining group life. We hypothesized that the victimization characteristic of ethnic cleansing is most likely in the densely settled areas of Darfur, where opportunities and incentives for attacks and strains on resources are greatest.

This hypothesis is consistent with the Malthusian view of population growth previously applied to the Rwandan genocide by Jared Diamond. ${ }^{101}$ According to Diamond, "population and environmental problems created by non-sustainable resource use ... ultimately get solved in one way or another: if not by pleasant means of our own choice, then by unpleasant and unchosen means, such as the ones that Malthus initially envisioned." 102 Yet Diamond is not an environmental determinist, even though he argues that "population pressure was one of the important factors behind the Rwandan genocide." 103 He further allows an important role for ethnic hatred, observing that:

I'm accustomed to thinking of population pressure, human environmental impacts, and drought as ultimate causes, which make people chronically desperate

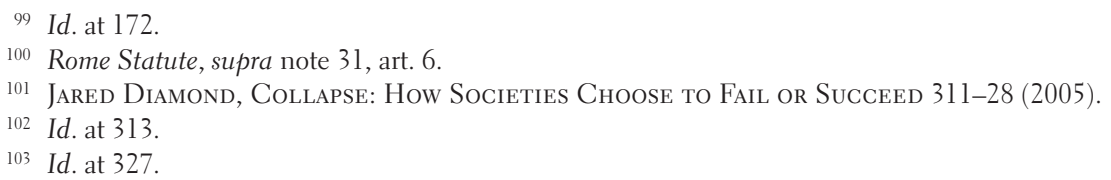


and are like the gunpowder inside the powder keg. One also needs a proximate cause: a match to light the keg. In most areas of Rwanda, that match was ethnic hatred whipped up by politicians cynically concerned with keeping themselves in power. ${ }^{104}$

This last reference to the role of politicians controlling the State and molding what we call "collective racial intent" fits well with Flint and de Waal's description of a Sudanese security cabal in Khartoum that unleashed the Janjaweed militias on black African groups in Darfur as an explicitly planned policy. ${ }^{105}$

The final pieces of our descriptive portrait of the ADS sample involve its description of genocidal victimization. The classical understanding of genocide emphasizes the intentional taking of lives that characterizes the destruction of a group. We have noted that a more contemporary approach to genocide also focuses on the deliberate infliction of physical conditions of life on a group calculated to bring about its destruction. Obviously both are important and both are included in Article II of the original Genocide Convention definition. ${ }^{106}$

Our measurement approach involved using a report section from each survey that recorded incidents of victimization. Respondents reported attacks on themselves, their families, and their settlements, which involved bombing, killing, rape, abduction, assault, property destruction, and theft. ${ }^{107}$ Each respondent therefore reported for him or herself together with his or her settlement.

We created a total victimization severity score based on the common law seriousness of the incidents reported for attacks on the settlements. We aggregated reports of specific incidents experienced or witnessed by each respondent in the settlement. ${ }^{108}$ We assigned the following values to the incidents: five to reported killings; four to sexual violence or abductions; three to assaults; two to property destruction or theft; and one to displacement. ${ }^{109}$

To illustrate the coding of the incidents in the severity scale, consider the example of a thirty-five-year-old Masalit woman with a total severity score of fifty-two. ${ }^{10}$ The attack reported by this woman occurred in a village near Masteri. Sudanese government troops and Arab Janjaweed militia attacked her village on September 1, 2003. Her report included twenty incidents during the attack that occurred that day. Her report includes herself, her family, and others in the village. During the attack, she was beaten (severity score of 3) and raped (4). Her father was severely beaten (3) trying to protect her, and he was subsequently abducted (4). Some women from her village were abducted (4) and held for two hours. They were beaten (3) and raped

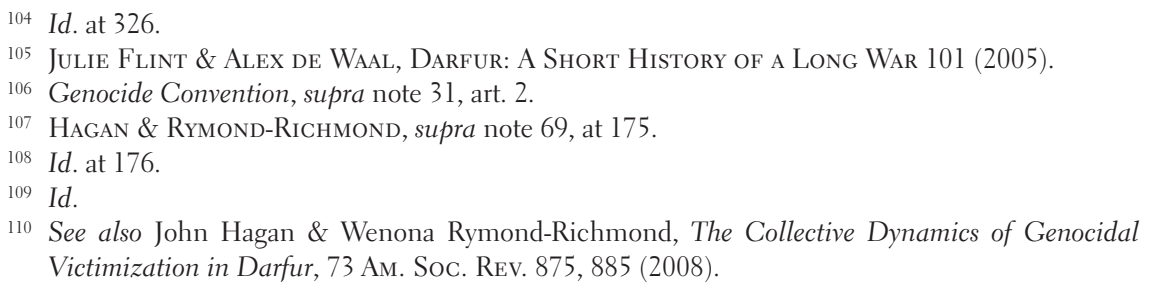


before being released. Another group of women (ages ranging from 16 to 20) were raped (4), and she personally witnessed one of the rapes and heard about the rapes from other victims. Additional villagers, including her brother, were beaten (3), shot (3), and stabbed (3). She witnessed dead bodies (5), all male, some of whom had their throats cut, and others that were shot in the head. Her village was completely destroyed (2), except for three huts that were on the far edge of the village. Theft occurred (2), including that of livestock, food, and water pots. She reports there was no rebel activity in or around her village. The only defense the villagers had was a few spears, which were no match for the attackers' guns, knives, aircraft, and pickup trucks with mounted guns. She entered Chad in February 2004, becoming one of the two to three million Darfurians displaced (1) from the mass atrocities.

To the extent that ethnic cleansing and genocide victimization encompass a group "in whole" - as, for example, a "scorched earth" policy would imply - there might be little within- or between-settlement variation in numbers of deaths or severity of victimization of the kind whose quantitative measurement we have just described. All would be victimized. On the other hand, to the extent that this group victimization is "in part," there should be variance in both within and between settlement outcomes. For the criminological and legal reasons we have indicated, we were particularly interested in determining the role that racial intent played in explaining variation in Sudanese state organized victimization, along with the Janjaweed militias, of the African groups and settlements.

Our interest was thus in the settlements as much as the individuals who are the victims of the Darfur conflict as represented in the ADS sample. The hypothetical process examined in our analysis is expressed in Figure 8.3. We analyze the combined roles of GoS forces with Janjaweed militias in racially targeted mass atrocities, as well as in the selective protection of nearby Arab villagers. Selective protection as

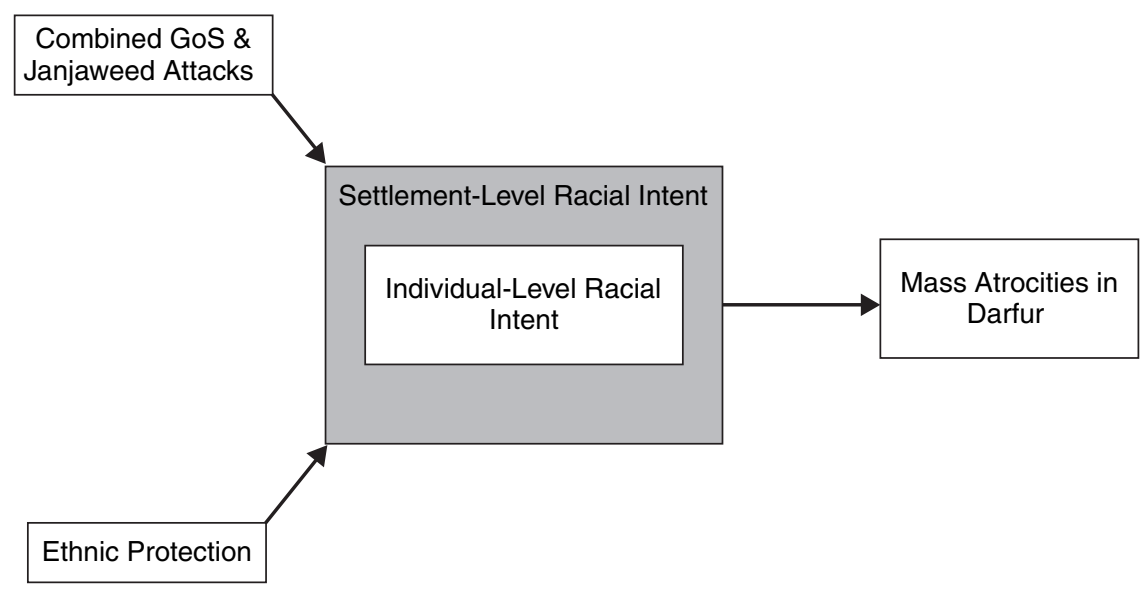

FIGURE 8.3. Combined roles of GoS and Janjaweed with ethnic protection in racial targeting of ethnic cleansing and mass atrocities in Darfur. 
well as predation can be an instrumental way of separating "us" from "them" in an organizational dynamic of ethnic cleansing that results in mass atrocities.

We summarize the most important aspects of this analysis in two maps. We begin with the distribution of the racial epithets heard during attacks by the ADS respondents. First, we consider how racial epithets were distributed in terms of the characteristics of the individuals who heard them - that is, we answer the question: Who heard these epithets most often? Second, we consider how the reporting of these epithets varies across the settlements - that is, we answer the question: Where were these epithets heard most often?

At the individual level, men reported hearing racial epithets more often than women. ${ }^{11}$ This is probably because women are less likely than men to know the Arabic words of the shouted epithets. Respondents also indicated they heard racial epithets less often in settlements with rebels. ${ }^{112}$ This finding is strongly suggestive that the scorched-earth tactics of the attacks focused on civilians rather than on suspected rebels. Three of the four African groups - the Fur, Masalit, and Jebal - more often reported hearing racial epithets than did the Zaghawa. ${ }^{113}$ This is likely because the Zaghawa were more often victims of bombing and air attacks than other groups there is more opportunity to hear the epithets during ground attacks. ${ }^{114}$ Epithets were reported less often during the first wave of attacks than at other times, ${ }^{115}$ which suggests that the racialization of the attacks increased over the duration of the conflict.

Map 8.1 portrays the variation in reported racial epithets across the settlements. It indicates variation in the proportion of respondents reporting epithets with circles of increasing sizes (calibrated in quartiles) in the settlements. About half of the respondents in the top quartile heard racial epithets during the attacks. Thus, 45 percent of the respondents heard racial epithets in Kabkabiyah, where the militia leader Musa Hilal began his early attacks, and between 43 percent and 50 percent of respondents heard these epithets in settlements in southwestern Darfur - in Al Geneina, Masteri, Habilah, Garsila, Foro Burunga, and Benesi - the sites of attacks reported in the media as led by three other Janjaweed militia leaders. ${ }^{116}$ The latter sites are in the more fertile and densely settled areas of Darfur. ${ }^{117}$

Map 8.2 outlines the locations where news media and human rights groups reported attacks occurred that were led by four militia leaders - Musa Hilal, Hamid Dawai, Ali Kushayb, and Abdullah Shineibat. The approximate areas of their operations indicated in these independent reports are designated with triangular-shaped markings on Map 8.2. These are also the areas with high reports of racial epithets and attacks in Map 8.1.

111 Hagan \& Rymond-Richmond, supra note 69, at 178.

$112 \mathrm{Id}$.

113 Id.

114 Id.

115 Hagan \& Rymond-Richmond, supra note 69, at 178.

116 Id.

117 Id. 


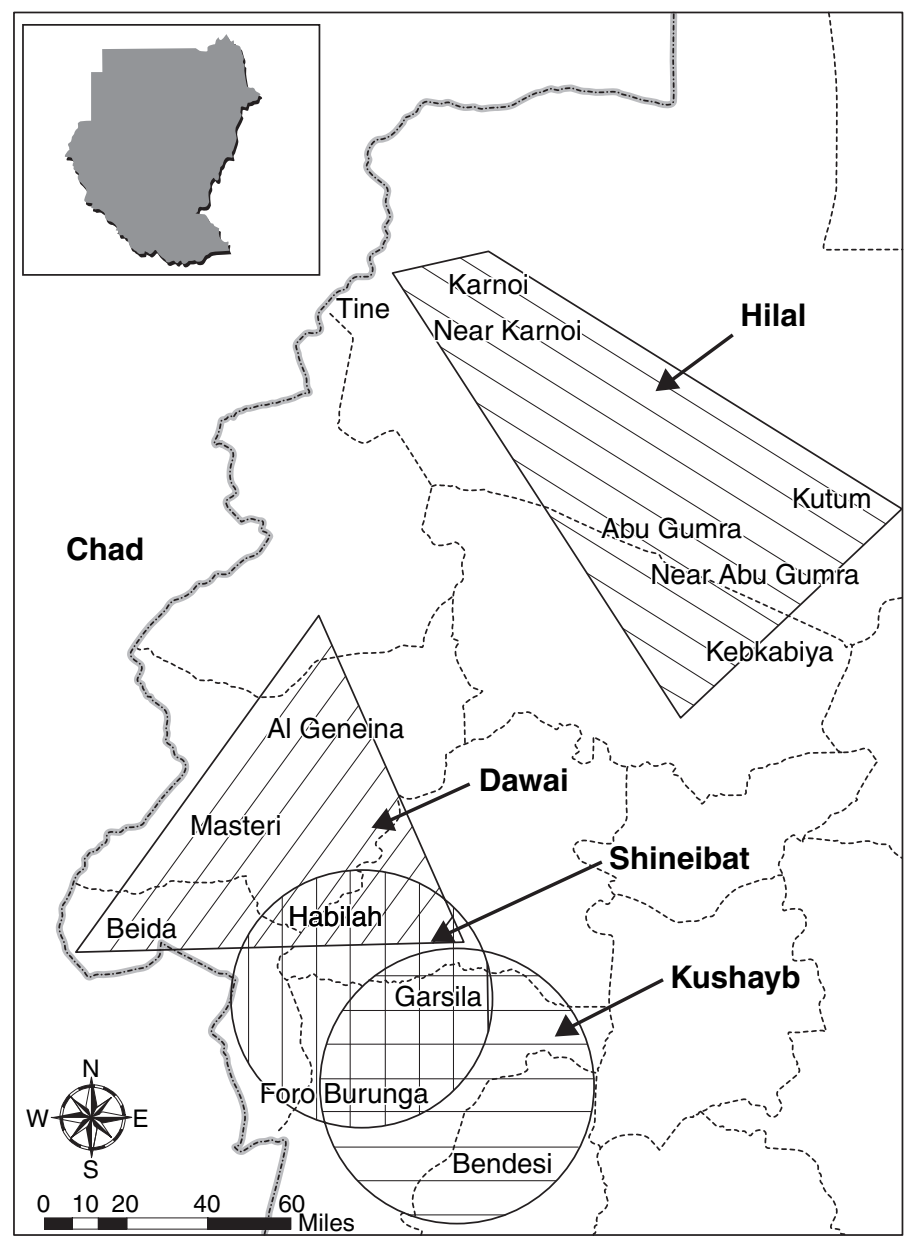

MAP 8.2. Janjaweed militia leaders' areas of operation.

Our analysis further revealed that the racial epithets we have emphasized as indicating racial intent were heard most often when the Sudanese government forces were joined with the Janjaweed in attacks and in areas of high settlement density. This finding, which reflects the effects of State military organization and policy as well as the opportunities and incentives of land-based resources that often motivate ethnic cleansing, is summarized with a bar graph in Figure 8.4. It indicates the following: When Sudanese and Janjaweed forces attack together, increased population density notably increases the hearing of racial epithets. When the Sudanese and Janjaweed forces attack separately, increased population density slightly diminishes the hearing of these epithets. Recall that the Sudanese and Janjaweed forces operate together in about two-thirds of the attacks. ${ }^{118}$ The effect of this combination of forces

118 Id. at 179. 


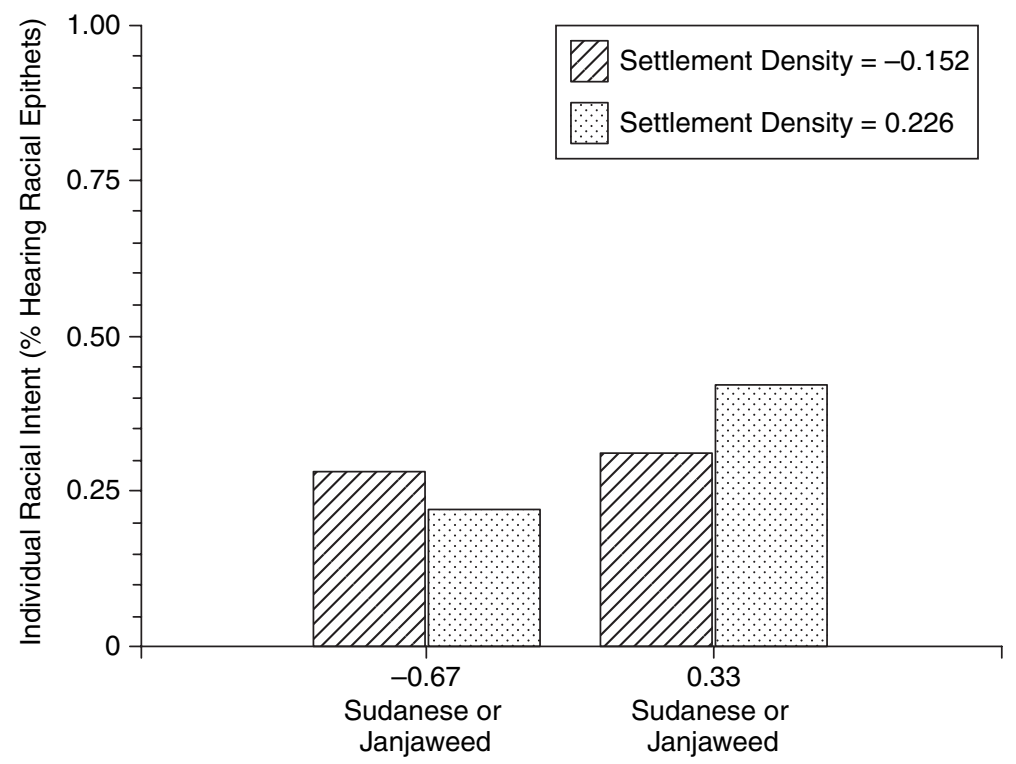

FIGURE 8.4. Cross-level interaction of separate and/or combined forces with settlement density on individual racial intent.

in the right side of Figure 8.4 - in areas representing higher population densities - is to approximately double the hearing of racial epithets from about 20 percent to more than 40 percent. This is compelling evidence of the organized policy role of the Sudanese State in intensifying the expression of racial intent by joining its military forces with the Janjaweed in attacks on densely settled areas of Darfur.

We next observe the impact of what we have called collective racial intent in two ways. Map 8.1 provided the first reflection of our finding of a significant effect of collective racial intent. The map showed that racial epithets were heard more often in the Kabkabiyah area, where the militia leader Musa Hilal launched his attacks, and in the southwestern settlements in West Darfur, where three other leaders had been active. Inside the circles on Map 8.1, which reflect these elevated reports of racial epithets, we also present the quartile ranks of the severity of total victimization, as operationalized earlier, as well as sexual victimization that we measured separately as the number of sexual assaults reported as occurring during the attacks. ${ }^{119}$

There is a clear tendency in Map 8.1 for the quartile ranking of victimization scores across settlements to coincide with the quartile ranking of reported racial epithets. Thus, top quartile victimization scores are found in five of the six settlements that also feature elevated racial epithets in the southwestern part of West Darfur. This part of West Darfur is more fertile and densely settled. The statistical models we present elsewhere show that these are also the areas where victimization is most

119 See also John Hagan, Wenona Rymond-Richmond \& Alberto Palloni, Racial Targeting of Sexual Violence in Darfur, 99 Ам. J. Pub. Health 1386 (2009). 


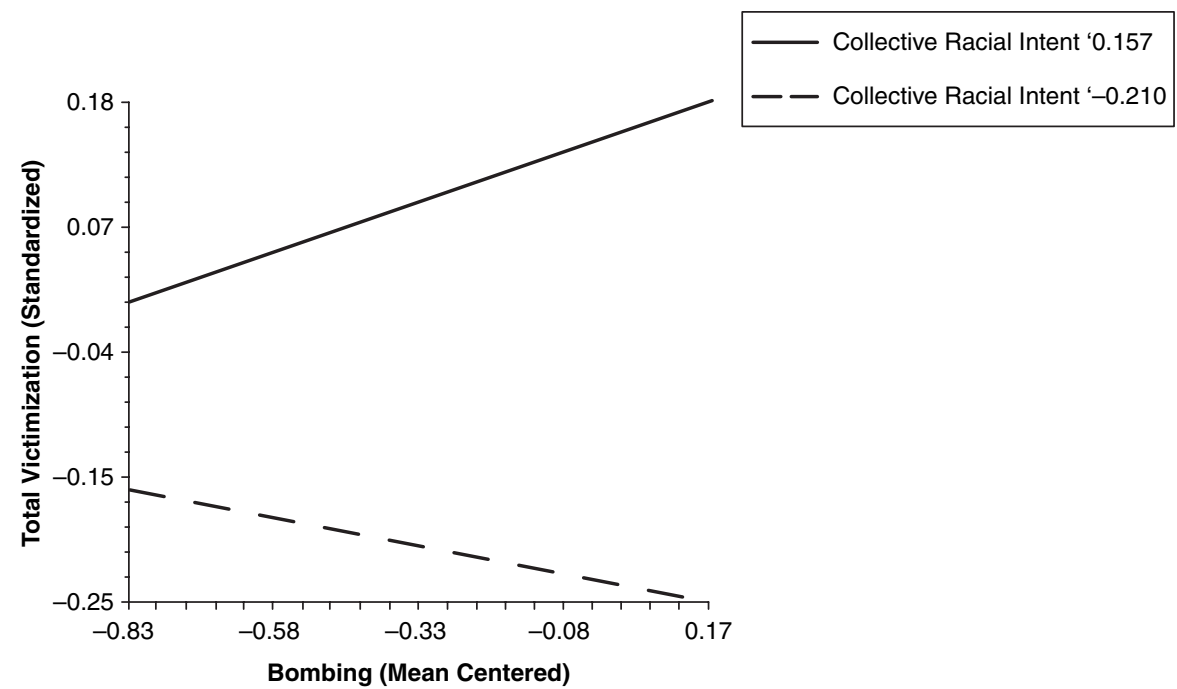

FIGURE 8.5. Cross-level interaction of collective racial intent with bombing on total victimization (standardized).

severe, and that this pattern is further mediated by the pervasiveness of the racial epithets and their collective effect in increasing victimization. ${ }^{120}$ This part of the analysis supports Diamond's metaphor, introduced earlier, that his expectation that collective racial intent is the transformative racial spark that ignites the powder keg of settlement density. ${ }^{121}$

There is also a pattern in Map 8.1 of higher-level victimization scores and racial epithet reports extending from Kabkabiyah, through Adar, and northward to Kornei. This pattern of scores reflects the northern line of attacks that Musa Hilal threatened in remarks reported in the market town of Kabkabiyh, as described in ADS survey interviews. ${ }^{122}$ It seems likely that if the levels of settlement density were as high in North Darfur as they are in the affected areas of West Darfur, that the pattern observed in this part of the map would be even more striking.

An important final finding about collective racial intent and bombing is summarized in Figure 8.5. This figure indicates that at lower levels of collective racial intent, the effect of increased bombing is associated with decreasing levels of victimization, whereas at higher levels of collective racial intent, the effect of increased bombing is to elevate total victimization. ${ }^{123}$ The basic thesis underwriting our analysis is that the Sudanese government enlisted the Janjaweed militias and channeled their hostility toward black African groups as a means of more effectively gaining control over the Darfur region - out of fear that this region was escaping government control. Given

120 Hagan \& Rymond-Richmond, supra note 69, at 177-82.

121 Diamond, supra note 101, at 326.

122 Hagan \& Rymond-Richmond, supra note 69, at 181.

123 Id. 
that the bombing by GoS planes is entirely under Sudanese State control, the combined use of the Janjaweed militias and government bombing is particularly striking evidence of the use of State power to divide and victimize subordinate groups. Figure 8.5 supplements the earlier findings in showing how, especially in densely settled areas, the concentration of bombing and collective racial hostility against African groups, such as the Fur and Masalit, produces elevated levels of victimization. The Sudanese government directed the bombing and enlisted the Janjaweed in racially animated attacks that intensified victimization. This is evidence that a joined, collective intent was enacted and accomplished.

\section{CONCLUSIONS}

We propose the acceptance of a definition of ethnic cleansing, such as Petrovićs, which emphasizes the enactment of an explicit policy of elimination or removal by one group against another that is defined in religious, ethnic, national, or racial terms and is organized in relation to an identified geographic area by military or sociopolitical means ranging from discrimination to extermination. Scientific research, legal scholarship, and judicial decision making can all play a role in further identifying the more exact boundaries of ethnic cleansing. More specifically, we argue that establishing the occurrence of ethnic cleansing may characteristically involve a mixture of social scientific criminological and legal evidence, with the criminological evidence playing a leading role. The challenge is to fully delineate the boundaries of ethnic cleansing in relation to genocide. Scheffer's distinction between atrocity crime and atrocity law creates a space in which this kind of documentation and analysis may occur. We have considered how this kind of documentation and analysis was undertaken in Kosovo and Darfur. These are only examples. Unfortunately, there is no shortage of other settings in which this work may be furthered. 